

\title{
CURRIE AND ECLAC: AN APPROACHING TO DEVELOPMENT THEORY
}

Camila Franco Restrepo, Carlos Alberto Ruiz Martinez ${ }^{1}$

\begin{abstract}
The main purpose of this paper is to stress the need for developing theoretical framework which involves the characteristics of the model presented by the Colombian-Canadian economist Lauchlin Currie along with the ECLA's ideas, particularly those developed by Raul Prebisch. Those elements let to establish a differential analysis that synthesized in a proposal emphasized in: the role of economic structures within the policy recommendations, including leading sectors to enable the economic transformation and defining growth as a selfgenerating process that encourages innovation and institutional renovation.

The paper shows a historical characterization of Colombian economy within ECLAC and Currie framework to compare the practical and theoretical view and the possible failures with their applications. Finally, this paper wants to vindicate the role of this brilliant economist whose ideas have been latent in new proposals but are not recognized as part of his theoretical work. It is also an incentive for developing a research project to find a macroeconomic theory for school ECLAC.
\end{abstract}

Keywords: Developing countries; ECLAC; Currie.

JEL Classification: B29, 010, 043, 054.

\footnotetext{
${ }^{1}$ Estudiantes Economía de la Universidad Nacional de Colombia. Correos electrónicos: cafrancore@unal.edu.co, caruizma@unal.edu.co
} 
La Colección Econografos considera para publicación manuscritos originales de estudiantes de pregrado de la Facultad de Ciencias Económicas de la Universidad Nacional de Colombia, que hayan sido propuestos, programados, producidos y evaluados en una asignatura, en un grupo de estudio o en otra instancia académica.

\section{Econografos Escuela de Economía ISSN 2011-6292}

Econografos FCE puede ser consultada en el portal virtual: http://www.fce.unal.edu.co/publicaciones/

Director Centro Editorial-FCE

Álvaro Zerda Sarmiento

Equipo Centro Editorial-FCE

Sergio Pérez

Juan Carlos García Sáenz

Diego Felipe Gutiérrez Bedoya

Maria del Pilar Ducuara López

Contacto: Centro Editorial FCE-CID

Correo electrónico: publicac_fcebog@unal.edu.co

Este documento puede ser reproducido citando la fuente. El contenido y la forma del presente material es responsabilidad exclusiva de sus autores y no compromete de ninguna manera a la Escuela de Economía, ni a la Facultad de Ciencias Económicas, ni a la Universidad Nacional de Colombia.
Rector

Ignacio Mantilla Prada

Vicerector General

Jorge Iván Bula Escobar

\section{Facultad de Ciencias Económicas}

\section{Decano}

José Guillermo García Isaza

Vicedecano

Rafael Suárez

\section{Escuela de Economía}

\section{Director}

Álvaro Martín Moreno Rivas

Coordinador Programa Curricular de Economía

Raúl Chamorro Narváez

\section{Centro de Investigaciones para EI Desarrollo CID}

Director

Jorge Armando Rodríguez

\section{Subdirectora}

Vilma Narváez 


\section{Introduction}

Neoclassical theory provides a theoretical framework which is the base of many policymakers to do recommendations. However, we can observe that although in some cases we get the expected results in most of cases those results differ from reality and make explicit the problem of how to guide our country towards development to ensure social welfare. For some economists, the question remains why not be eclectic about the different schools of economic thought? These schools independently have allowed significant and important contributions Advocates theoretical improvement through constructive criticism, however, have lost the economist's objective which is to guarantee social welfare..

The specific aim is to show the similarities and differences among the structuralists (ECLAC) and the economist Lauchlin Currie, in order to give the bases for a new development theory, assessed concisely in the Colombian historical experience.

\section{Who is Lauchlin Currie and what you propose?}

Lauchlin Currie was an economist at the London School of Economics and a PhD from Harvard University. His greatest contributions as a theorist and researcher are given in the areas of growth and development. In Colombia, developed and managed the creation of today's Department of National Planning and Savings and Housing Corporations also be the creator of many economic policy plans as Operation Colombia and the Four Strategies. Throughout this brief description the reader find the great proximity among Currie with authors such as John Maynard Keynes and Allyn Young.

As a first step to understanding his proposal is important to clarify their definitions of concepts involving the work: growth, development and progress. First, growth is defined in terms of positive change in per capita income, i.e., occurs in quantitative terms, the development includes growth but undoubtedly in the case of countries in developing involves the scope of enjoyments developed nations, and finally the welfare is given by the "frustration" of the individual compared with others. Development needs for growth, but this is not a goal, for Currie development is the way to abolish poverty and to break with what he called the "vicious circle of poverty."

Under this framework, equality should be treated not in terms of "arithmetic division of income" but in terms of lifestyle, spending levels and opportunities. There is a stronger psychological element; hence it raises the necessity to include different aims for different countries, identifying the non-economic motivations.

The Currie's with these concepts is driving the discussion towards the growth rates and the eradication of poverty through income redistribution and the existing property, but warns the political problem "populist" that can end in dictatorship, then your recommendation is the same as Okun, Equality and efficiency while certifying individual liberties.

Currie unlike other contemporary authors, he emphasizes in the relevance of environment which we all know is the basis for the survival of humanity and should be clearly aimed at the development objectives. 


\section{Currie: Concepts and ideas}

Influenced by Keynes, he believed that the best way to abolish poverty by ensuring development is the economic government planning, these ideas put into practice in Colombia through "Operation Colombia" and "Four strategies" in the 1960 and 1972 respectively.

These plans are responses to the author's concern for the problems presented in the agricultural sector that mobilized more labor than could be observed, together of labor deployment between rural and urban, low productivity, and the gradual introduction of technical change. On the other hand also arise from the need to segment the solutions, in other words, although we must recognize the historical reference for developing countries, latent need is not to apply the same theories that worked for these countries but to provide a diagnosis particular and to attack the problem with some planning.

We could identify this Currie's vision with Dual Development Theory's scheme which raises two sectors: the first, that's tech labor intensive (agriculture), and other emerging sector that has medium tech capital intensive that is called "Leader Sector" with particular characteristics.

It shows that is necessary a government intervention but with limitations, so the hardest part is to found what should be the fields intervened and we should not be interpreted as a socialist theory.

The policy basis of the empirical work of Currie calls for macroeconomic theory of growth based on an industry leader, which is "the identification and promotion of specific private sectors to achieve an increase in the rate of growth" (158). Behind this is the concept of reviving Keynesian aggregate demand but differs from this author because it is not considered feasible an increase in the deficit.

The leader industry seeks linkages which in turn permit the enlargement of market returns idea of Allyn Young, also based on the work of A. Smith when he defines that the only limit is the division of labor market size and must be made to increase, either by reducing transportation costs or by the idea of previous authors referred to the link other sectors by positioning an easier and to increase effective demand (Following the proposal of J.Say) in the words of Currie

"In my case I suggested that to accelerate the growth rate should concentrate efforts on some sector or sectors as showing increasing returns, but because they can respond to exogenous stimuli, that is, independent of the aggregate rate of growth because they exist in latent demand for their products and, preferably, that this demand has a high income elasticity, and that can become large enough that their impact on the economy is significant "(National University of Colombia, 1993).

\section{Structuralist and ECLAC}

Structuralism strongly linked to ECLA School that is located temporarily from the 40s to the 70s, followed by a period known as "neo structuralism" by some as Bielschowsky. 
For our purposes we consider the basic ideas of structuralism, particularly those that belong to Argentine economist Raul Prebisch although we highlight the contributions to this school by Fernando Cardoso, Celso Furtado, among others.

ECLA School stems from the historical necessity to develop a cyclical theory of his own to explain the dynamics characteristics of Latin American and could not be explained by neoclassical theory. This theory was for many the hope in terms of developmental policies because tabled the dependence relationship among our nations and the United States and Europe.

Their analysis is based on the Latin American economies is characterized by: i) specialization in the primary sector goods and low productive diversity (complementarity reduced cross and vertical integration), ii) very different levels of sectorial productivity and unlimited supply of labor for incomes close to subsistence, and iii) institutional (state, agriculture and business composition, etc.) disinclined to investment and technical progress. (Bielschowsky, 2009)

The above ideas suggest a different approach to the problems of our countries, which leads to a number of explanations as dependency theory, center-periphery known to all. In the essay "Hacia una teoria de la transformación" refers to the "peripheral capitalism" where (in a personal opinion) condense the internal dynamics and pose a theoretical solution. In peripheral capitalism there is a top layer that tries to mimic the consumption and "culture" of central capitalism, this top layer absorbs most of the surplus, which in turn is depressed by the "orbit of the state" and "sphere of the market" to expand the process of imitation to layer "upper middle", that is Prebisch called "structural mutation".

In this system the redistribution of the surplus is minimal because of top layer absorption. So one of the first proposals of the theory of transformation is the redistribution of surplus labor force because it guarantees welfare and the creation of new capital from the lower ranks. This distribution is given by a neoclassical framework where there is no surplus but simply entrepreneurial profit.

The policy area is based on a struggle for political power; this transformation becomes a "trophy" of emerging political dynamics because of the intermediate pressure after economic dislocation. In this case the role of the government is to divide democratically the surplus. Prebisch describes this process as a political-economic synergy between socialism and liberalism: socialism because it must use the surplus in the best way possible by ensuring equality and liberalism in the concept of freedom, both political rights and the market.

The solution may be listed as: the introduction of technical change, a state planning role when "budget" surplus, a call for increased production and exports in manufacturing.

\section{Currie and ECLAC in the Colombian economic history}

In Colombia, Currie makes the theory a fact through two plans: "Operación Colombia" and the "Cuatro Estrategias". The first one aimed to increase market size by increasing the size of the production. 
In the diagnosis made in "Operación Colombia", limiting growth is the lack of savings or low investment dynamics but the misallocation of resources that originate in the immobility of factors and not enough demand.

Currie found thanks to Operation Colombia (1961) several problems: an imbalance in the balance of payments, low productivity in most farm workers and the consequent limitations of the industrial market, backwardness in education, housing deficit and public services, rapid population growth and a very low level of efficiency of public administration.

Operation Colombia noted bureaucratic problems and formalities that hinder entrepreneurship and investment. On the other hand showed the problem of archaic methods of tax collection reflects unnecessary bureaucracy, delay and a waste of time pressing down on the efficiency and productivity of public administration concluding a need to modernize the state. Raised in short, a conscious and deliberate acceleration of urbanization and industrialization through the modernization of agriculture, to avoid perpetuating structure of colonial agricultural production.

For Currie sector complying with the features to be built was the leading sector since its intrinsic characteristics facilitated the absorption of labor from the field.

On the other hand the four strategies (1970-1974) has many similar points to those of Operation Colombia, whose diagnosis now focuses not on the lack of capital, as in previous studies, but insufficient effective demand, resulting low levels of income of the population (Moncayo, 2002)

In other words the problem was not in the capital or labor but in institutions that hinder the mobility of workers and led to inefficient use of resources. Had to find a sector capable of generating gainful employment and have a multiplier effect on the overall economy. The idea in mind of these policies was the creation of multipliers act as a virtuous cycle of production, demand and growth.

Taking the construction industry and housing as the leader for a system of financing and credits Currie converted to the parent of UPAC, controversial to the clearing in the nineties. The key points of the four strategies were: emphasis on housing, export promotion, improve agricultural productivity through the land, creating relatively progressive taxes reduce inequality.

For the private sector is sought by a process of capitalization of capital reserves and tax exemptions on dividends, which would allow capital investment. The obvious risk to all these changes was inflation. As results showed a growth of nearly 6\% of the industry rather than construction, rural mobilization was descended marginally decreased productivity and increased inflation as is stipulated as the major critics.

The fundamental stability is also key to policy Currie was not warned the effect on inflation, and led not a serious problem but in a significant increase in the price level and fiscal deficit. Monetary policy must be consistent with these objectives, but not for us to go into it.

Moreover, after the great recession, and in the postwar era, it became dormant for many countries the need for protection. Latin America was vulnerable and had a picture with 
incipient capital accumulated under this framework appears ISI. Import substitution industrialization, an idea that was attributed to the ECLA School was still in training.

Industrialization was the production for the domestic market for industrial goods and gradually replacing imported goods. It also covered the same range for agricultural goods. As Ocampo says, Avella, Bernal, in his compendium Errázurriz one of the highlights of this phase was 50 tariff reforms, like the Industrial Development Agency at this time also created Ecopetrol in 1948.

However, there are many who argue that there was a misrepresentation of the ideas of Prebisch and ECLAC, it states that the error of this system was completely closed, i.e. neglect and join efforts in building a sector manager export of manufactures. In the case of Colombia can be attributed also to the institutional-political element to the support of leading companies for convenience, where personal interests prevailed, rather than the positioning strategies of sectors or industries that really needed it.

Analysis Romary like Torp conclude that this period as in most Latin American countries like Argentina, Brazil, Colombia, Chile, Mexico and Uruguay do not correspond to what ECLAC: "The theory favored the moderate selective and temporary protection with a view to potential new exports, supported by inflows of foreign capital to overcome various bottlenecks, but understanding that it was mainly public money."(Torp, 2000)

Bajrarj also highlights the shortcomings of ECLAC thinking at this time by failing to rule as defenders of the idea that this "protection" on the economy would penalize exports. Prebisch although it was clear this gap. The political response to this error came in the late 60s when President Carlos Lleras Restrepo that promoted exports.

On the other hand also blames political favors awarded to companies with little capacity or expansions, many of them were small industries in small towns with poor roads.

According to Currie also makes a policy analysis of ECLAC criticizing the plan foresee any major income for the country based on the investment of the funds allocated under the assumption that any item of investment in national accounts, imply an increase in the real output per person. Years after leaving the only option plan to the Finance Ministry to increase the debt to mitigate the austerity program. (Males, 2009)

\section{From a very common need}

The comparison between Currie and ECLAC, will allow us to make a brief conclusion that we consider fundamental elements of the two currents in proposing a theory of development. Both are signs of economic theory and regional identity.

One might think that both Currie as ECLA are shown as a non-Marxist alternative to the market system and economic liberalism in all its expression. The point is sympathetic to the idea of a state planner, without falling into what both Prebisch and Currie categorized as socialist dictatorships. For the first planning aims at "better" use of the surplus, while for Currie to say nothing of surplus also lies in channeling capital activity to absorb more labor, intuitively are similar. 
Another common point between these two theories is the need to focus efforts not only in agriculture but in industry or for Currie is the leading sector for each economy. With that not to say that agriculture should be neglected, however tecnificarla and shift resources to any line that allows linkages and reduce unemployment.

Currie made a call to ECLAC at that time whom he accused of abusing the goodness of the estimators, linking economic growth with higher income and social welfare assuming an obvious relationship to Currie was not so obvious:

"The general welfare is an intangible concept that defies precise measurement, and

Economists have never liked having to do with, although the subject matter of their science. The economic literature generally point to the dangers that surround the

identification of welfare with the increase in income, and recognize that the conditions under which performs the work, rest, entertainment, health and education are all important factors in the general welfare or standard of living (more and more, however, the latter term is identified with monthly income or "real"). Even the same people are inclined to give much more interest income relative to these other factors"

\section{Call for a new theoretical development}

These two "theories" are a call to find answers particular peculiarities intrinsic respect. And are consolidated as an alternative development of the neoclassical growth theories that have been prioritized against a target figure of progress need to guarantee welfare, i.e. the proposal for science is to remember who works for the good of man and not to fetishism of indicators which, while diagnoses of social dynamics are not an end but a measurement tool.

Currie is a synthesis derived from neoclassical influence Young, keeping in line with sustained growth when increasing returns are guaranteed. This would believe that is the biggest difference with the school ECLAC.

Derived from a common fault why these proposals were not successful highlights the neglect in capturing the political element and institutions of the time. The errors in the case of Colombia, and we assume that in Latin America also were political obstacles, which cleared the way for the neoliberal trend over a long period of time, which also failed but achieved in one or another qualitative improvements that form the economic paradigm appears as though successful social demands embodied in inequality and poverty remain stagnant or deteriorating growth almost invisible, is indicated the need to consider the institutional and political element structural and cyclical in the formulation of new proposals.

Another recommendation may be part of a latent weakness in these approaches is considered as a relevant variable exogenous shocks, the current crisis and globalization demand we find guesses to help us deal with abrupt changes do not necessarily endogenous to our economy.

The greater distance between these two theories of classical inspiration received from Young and present in the growth models of Currie that are viewed with suspicion since most of the ECLA. However, after recognizing that the strict protectionism is not the solution and the need 
to focus on exports to developing the manufacturing industry and possibly incentives similar to those used by these two schools, this is not a defense to oblivion agricultural sector crying out for modernization and to be rethought in order to satisfy domestic demand rather than external.

The roads are open, as stated earlier rather than seeking to deepen the differences between the theories is best to seek joint solutions based on specific and in order to improve the lives of individuals.

Be reconciled into a single theory, since differences between these may be omitted and insignificant. The proposal is clear, a model to analyze the characteristics of lationamerica, understanding that serves as a central market economy, and that reason being its main enemy of poverty and inequality, thus seeking development through accelerated economic growth, the strategy at this point is a boost to industry and manufacturing but not from the ban on the import or export.

\section{References}

[1] Bielschowsky, R. (ABRIL de 2009). Sesenta años de la CEPAL: estructuralismo y neoestructuralismo. Recuperado el 2011 de septiembre de 1 , de CEPAL:http://www.eclac.org/cgiin/getProd.asp?xml=/revista/noticias/articuloCEPAL/0/3 5860/P35860.xmlEtxsl=/revista/tpl/p39f.xslCtbase=/revista/tpl/top-bottom.xsl.

[2] Moncayo, E. (2002). Nuevos enfoques de política regional en América Latina: El caso de Colombia en perspectiva histórica. Recuperado el agosto de 2011, de Ideas Repec: http://ideas.repec.org/p/col/000118/003288.html

[3] http://www.eclac.org/cgiin/getProd.asp?xml=/revista/noticias/articuloCEPAL/0/35860/P 35860.xmlEtxsl=/revista/tpl/p39f.xslEtbase=/revista/tpl/top-bottom.xsl.

[4] Ocampo, J. A. (2007). Historia Económica de Colombia. Bogotá: Planeta.

[5] Prebisch, R. (diciembre de 2008). Hacia una teoría de la transformación. Recuperado el agosto de 2011, de CEPAL: www.eclac.cl/publicaciones/xml/4/34904/RVE96Prebisch.pdf

[6] Torp, R. (2000). De América Latina en los años 50 y 60. Recuperado el Septiembre de 2011, de CEPAL: www.eclac.org/publicaciones/xml/4/10704/lcg2103e.pdf

[7] Universidad Nacional de Colombia. (1993). Cuadernos de Economía No 18-19. Bogotá: Departamento de teoría y política económica UNAL.

[8] Varón, M. (2009). Quién decide qué y por qué Relaciones entre Ejecutivo y Legislativo en materia de Planeación. Recuperado el septiembre de 2011, de Departamento de Planeación Nacional: http://www.dnp.gov.co/LinkClick.aspx?fileticket=PrKbpwx\%2F5cI\%3DEttabid=897 